\title{
Pelleting of diet for weaning pigs of different initial weights
}

\author{
Diego Surek ${ }^{1 *}$ Samuel Augusto dos Santos $^{1}$ Chayane da Rocha ${ }^{1}$ Marcelo Ivan de França ${ }^{1}$ \\ Geraldo Camilo Alberton ${ }^{1}$ Alex Maiorka ${ }^{1}$
}

${ }^{1}$ Universidade Federal do Paraná (UFPR), 80035-050, Curitiba, PR, Brasil. E-mail: diego_surek@hotmail.com. *Corresponding author.

\begin{abstract}
Physical form effect of the pre-starter diet supplied during the post-weaning period from 21 to 41 days of age on diet digestibility and animal performance in terms of zootechnical performances of light-weight (5.82kg) and heavy-weight weaning piglets (6.32kg) was evaluated, as well as the residual effects of the treatments until slaughter. Forty-eight female pigs at 21 days of age were evaluated. The experimental design was completely randomized in a $2 x 2$ factorial scheme (meal/pelleted diet vs. light-weight/heavy-weight piglets), with six replicates for the nursery phase and 12 replicates for the growing-finishing phases. Animals received the experimental diet from 21 to 41 days of age. Data were analyzed with ANOVA, setting the significance in 5\%. Feeding with the pelleted diet resulted in a 39\% greater daily weight gain and a $28 \%$ greater feed conversion rate for piglets from weaning to 40 days of age. Pelleting also resulted in a decrease in feed wastage during the first week after weaning (9.15\% for meal diet vs. $1.68 \%$ for pelleted diet) and; consequently, the results showed an increase in feed consumption. Digestible energy of the pelleted diet $\left(3,626 \mathrm{kcal} \mathrm{kg}^{-1}\right)$ was greater than that of the meal diet $\left(3,424 \mathrm{kcal}^{\mathrm{kg}} \mathrm{g}^{-1}\right)$. The physical form improved the performance of weaning pigs and the digestibility of the pre-starter diet, but there wasn t residual effect of the physical form and the weight of a piglet at weaning on live weight at slaughter. Key words: feeding, pellet, swine, thermal processing.
\end{abstract}

Peletização da dieta para leitões recém-desmamados com diferentes pesos iniciais

RESUMO: Avaliou-se o impacto da forma física da dieta pré-inicial em leitões leves $(5,82 \mathrm{~kg})$ e pesados (6,32kg) no período pós-desmame sobre o desempenho zootécnico e digestibilidade da dieta, bem como o efeito residual dos tratamentos até o abate. Foram utilizados 48 leitões fêmeas com 21 dias de idade, distribuidos em delineamento inteiramente ao acaso, em esquema fatorial $2 x 2$ (farelada/peletizada vs. leitões leves/pesados), com seis repetições na fase de creche e 12 repetições na fase de crescimento e terminação. Os leitões receberam as dietas experimentais dos 21 aos 40 dias de idade. Os dados foram submetidos à análise de variância ao nível de 5\% de probabilidade. Observou-se que a peletização melhorou em $39 \%$ o ganho de peso diário e $28 \%$ a conversão alimentar do desmame aos 40 dias de idade. Ao considerar a redução de desperdício da ração peletizada $(9,15 \mathrm{vs}$. 1,68\%) na primeira semana pós-desmame, a peletização da dieta proporcionou aumento do consumo de ração. Ao avaliar a digestibilidade da dieta, observou-se que a energia digestivel aumentou de $3.424 \mathrm{kcal}_{\mathrm{kg}}{ }^{-1} \mathrm{na}$ forma farelada para $3.626 \mathrm{kcal} \mathrm{kg}^{-1}$ na forma peletizada. A forma física da dieta proporcionou efeitos positivos sobre o peso vivo dos leitões desmamados e energia digestivel da dieta. Porém, não foi observado efeito residual da forma física ou peso ao desmame sobre o peso vivo ao abate.

Palavras-chave: alimentação, pelete, suínos, processamento térmico.

\section{INTRODUCTION}

The process of weaning and allocation to nursery facilities exposes piglets to changes in their physical and social environment. Moreover, the exposed piglets experience nutritional changes, such as the change from a milk-based diet to a solid-feed diet. This transition can be divided into two phases: the acute phase (first five to seven days after weaning, during which time the weaned pigs learn how to eat and resume a level of dry matter intake comparable to the pre-weaning phase) and the subsequent adaptive phase (BURRIN \& STOLL, 2003).

Several nutritional and non-nutritional factors influence and determine the zootechnical performance of animals after weaning, which is generally characterized by a decrease in growth rate. Nutritionally, in addition to the rate of feed consumption, the digestibility of the diet is one of the most important factors affecting zootechnical performance (MAHAN \& LEPINE, 1991). The heat processing of diets, such as pelleting, expansion, and extrusion procedures, can increase digestibility (LUNDBLAD et al., 2011).

A supply of pelleted diets to nursery piglets is generally acknowledged to reduce feed wastage and to improve zootechnical performance (HANCOCK $\&$ BEHNKE, 2001). Testing and optimization of the feed method processing is fundamentally important because it affects the viability of adopting a pelleted diet. The piglet characteristics at weaning are also 
important determinants of zootechnical performance, and piglet weaning weight is positively correlated with the subsequent growth rate (WOLTER et al., 2002). Compared to smaller piglets, heavy-weight piglets are characterized by a higher feed intake and weight gain during the period immediately following weaning (MAHAN et al., 1998).

The objective of the present study was to evaluate the effect of the physical form of the pre-starter diet on the diet digestibility and the zootechnical performance of light-weight and heavyweight piglets following weaning and their residual effects until slaughter.

\section{MATERIALS AND METHODS}

The study was conducted at the Laboratory of Pigs of the Universidade Federal do Paraná (UFPR). Forty-eight female piglets (commercial breed) that were weaned at three weeks of age were used. The piglets were transported for six hours from the pig production unit to an acclimatized nursery, where their initial weight was measured.

Each experimental unit at the nursery phase consisted of two ear-tagged piglets, $0.85 \mathrm{~m}^{2}$ pen with a plastic slatted floor and access to a nipple drinker and trough feeder $\left(0.45 \mathrm{~cm}\right.$ animal $\left.{ }^{-1}\right)$; animals remained in the nursery from weaning until 56 days of age. During the growing-finishing phase, the animals were relocated and grouped, maintaining the treatment scheme of the previous phase, with three animals per pen $\left(3 \mathrm{~m}^{2}\right)$. Weights were monitored until 130 days of age. During this period, each animal was considered an experimental unit.

Animals received diets of one of two physical forms from the time of weaning until 40 days of age. The following treatments were tested: 1 - heavy-weight piglets $(6.33 \mathrm{~kg})$ fed with a pelleted pre-starter diet; 2 - light-weight piglets $(5.83 \mathrm{~kg})$ fed with a pelleted pre-starter diet; 3 - heavy-weight piglets $(6.32 \mathrm{~kg})$ fed with a meal pre-starter diet; and 4 - light-weight piglets $(5.81 \mathrm{~kg})$ fed with a meal prestarter diet. Piglets did not have access to a selective feeder at the farrowing pen.

Diets were formulated according to ROSTAGNO et al. (2005) to meet or exceed nutritional demands, with both meal and pelleted pre-starter diets designed to be isonutritive and isoenergetic (Table 1). The corn used to formulate the diets was ground using a hammer mill with a $2 \mathrm{~mm}$ sieve (corn geometric mean diameter [GMD] of $650 \mu \mathrm{m})$. The meal diet and the pelleted diet had the same composition, with a GMD of $410 \mu \mathrm{m}$.
The pelleting (micropelleting) of the prestarter diets was performed by conditioning at a mean temperature of $55^{\circ} \mathrm{C}$, low temperature because of the pre-started diet complexity, and a vapor pressure of $1.5 \mathrm{~kg} \mathrm{~cm}^{-3}$ for 30 seconds, using a $\mathrm{CPM}^{\circledR}$ pellet mill, with a die measuring $50 \mathrm{~mm}$ in height and a $2-\mathrm{mm}$ hole diameter.

During the final nursery phase (41 to 56 days of age), all of the animals received the same pelleted starter diet $(3,350 \mathrm{kcal}$ metabolizable energy (ME), $21 \%$ crude protein (CP), and $1.3 \%$ digestible lysine). During the growing-finishing phase, all of the animals received the same pelleted growing diet from 57 to 100 days of age $(3,230 \mathrm{kcal} \mathrm{ME}, 19.25 \%$ CP, $1.05 \%$ digestible lysine) and the same finishing diet from 101 to 130 days of age $(3,230 \mathrm{kcal} \mathrm{ME}$, $17.75 \% \mathrm{CP}, 0.85 \%$ digestible lysine). The pelleting of the starter, growing, and finishing diets was performed using a Van Asrsen ${ }^{\circledR}$ pellet mill, with a die with a $55 \mathrm{~mm}$ height and a $4 \mathrm{~mm}$ hole diameter, with conditioning for 40 seconds at a pressure of $2.0 \mathrm{~kg} \mathrm{~cm}^{-3}$ and $80^{\circ} \mathrm{C}$. Diets were supplied ad libitum to all phases.

Animal performance was evaluated for the periods 21-28 days, 29-40 days, and 21-40 days of age. The following variables were analyzed: live weight (LW); mean daily feed intake (considering the offered, consumed, and wasted feed, minus the leftovers) (DFI); mean daily weight gain (DWG); and feed conversion (FC). Feed wastage (FW) relative to the total feed consumed $(\%)$ and to the feed consumption corrected for feed wastage (DFIFW) were calculated for the first seven days after weaning. A partial collection of feces was performed between 37 and 40 days of age in the morning and in the afternoon, and the collected samples were frozen. The acid-insoluble ash (AIA) content was determined according to VAN KEULEN \& YOUNG (1977) and considered as a natural internal indigestibility marker for the calculation of digestible energy (MOUGHAN et al., 1991; KAVANAGH et al., 2001).

Feces samples were thawed, homogenized, and dried in a forced-air oven at $55^{\circ} \mathrm{C}$ to a constant weight. After drying, the feces and feed samples were ground to $1 \mathrm{~mm}$ and the AIA, dry matter (DM), and gross energy (GE) contents were determined. The DM was determined at $105^{\circ} \mathrm{C}$, and the GE was measured using a bomb calorimeter. The AIA and GE were $0.29 \%$ and $4,610 \mathrm{kcal} \mathrm{kg}^{-1}$ for the pelleted diet, respectively, and $0.32 \%$ and $4,625 \mathrm{kcal} \mathrm{kg}^{-1}$ for the meal diet, expressed on a dry matter basis.

Animals were monitored during the subsequent phases to evaluate the residual effects 
Table 1 - Percentage composition and calculated nutritional values of the pre-starter diet (on natural matter basis).

\begin{tabular}{|c|c|c|}
\hline Ingredient & & $\%$ \\
\hline Corn & & 44.69 \\
\hline Whey powder & & 16.22 \\
\hline Soybean meal, $46 \%$ & & 15.00 \\
\hline Micronized soybean & & 7.60 \\
\hline Mix plus extrusion-cooked ${ }^{1}$ & & 7.50 \\
\hline Spray dried plasma & & 4.00 \\
\hline Cake residue & & 2.00 \\
\hline Dicalcium phosphate & & 0.60 \\
\hline L-lysine $\mathrm{HCl}$ & & 0.43 \\
\hline DL-methionine & & 0.24 \\
\hline L-threonine & & 0.22 \\
\hline Premix Vit/Min ${ }^{2}$ & & 1.50 \\
\hline Calculated composition & Unit & Value \\
\hline Metabolizable energy & $\mathrm{kcal} \mathrm{kg}^{-1}$ & 3.401 \\
\hline Crude protein & $\%$ & 21.65 \\
\hline Lactose & $\%$ & 12.00 \\
\hline Milk protein & $\%$ & 0.72 \\
\hline Calcium & $\%$ & 0.69 \\
\hline Available phosphorus & $\%$ & 0.54 \\
\hline Lysine dig. & $\%$ & 1.44 \\
\hline
\end{tabular}

${ }^{1} 37 \% \mathrm{CP}$, composed of poultry offal meal, corn, soybean protein isolate, antioxidant, and acidifier. ${ }^{2}$ Vitamin and Mineral Mixture, content per kg diet: Vit. A, 8000UI.; Vit. D3, 1500UI.; Vit. E, 9.8UI.; Vit. K3, 1mg.; Vit. B2, 3.5mg.; Vit. B12, 15mg.; Pantothenic acid, 15mg.; Nicotinic acid, 20mg.; Se, 0.160mg.; Mg, 45mg.; Cu, 52mg.; Fe, 100mg.; Zn, 1100mg.; I, 1.50mg.

of the treatments applied immediately following weaning. The LW, DFI, DWG, and FC were determined for the period from 41 to 56 days of age (the end of the nursery phase), and the LW was also determined at 100 and 130 days of age.

The experimental design was completely randomized in a $2 \times 2$ factorial scheme consisting of two physical form of pre-starter diets (meal/pelleted) and two piglet weaning weight (light/heavy), with six replicates per treatment for the nursery phase, including digestibility, and 12 replicates for the growing-finishing phase. Homogeneity of variance of data was tested using the Bartlett test, and ANOVA was performed to compare treatments. Significant interaction were identified according to the factors involved, means of the interaction were compared by Tukey's tests, at $5 \%$ probability.

\section{RESULTS AND DISCUSSION}

Pelleting the pre-starter diet resulted in an improved DWG and FC and a decreased FW during the first week following weaning $(\mathrm{P}<0.05$, Table 2$)$. There was no significant effect of pelleting on DFI (P 0.107). However, this lack of effect may have been attributed to the higher observed FW when the animals received a meal diet (9.15 vs. 1.68\%) during the first week following weaning (P 0.001) because the DFI-FW was greater for the pelleted diet than for the meal feed (P 0.019). Increase in DFI-FW might have been attributed to the processing because the meal feed had a GMD of $410 \mu \mathrm{m}$ and pelleting caused the pelleted feed to be relatively less powdery. MOREIRA et al. (2001) studied the replacement of corn with pre-gelatinized corn and suggested that the fine particle size of the raw material negatively affected feed intake.

Similar performances have been reported by $\mathrm{OHH}$ et al. (2002), who tested a corn, soybean meal and dairy product-based diet conditioned at $35^{\circ} \mathrm{C}$ and pelleted using a die with a $2.8 \mathrm{~mm}$ diameter hole and observed improvements in the DWG and FC accompanied by an increased DFI during the two weeks following weaning. XING et al. (2004) pelleted a corn, soybean meal and dairy product-based diet conditioned at $60^{\circ} \mathrm{C}$ and observed an increase in DWG during the first two weeks following weaning, a decreased DFI from 15 to 35 days following weaning, and improvements in FC during all periods compared to the corresponding meal diet. 
Table 2 - Effect of the physical form of the pre-starter diet on zootechnical performance during the period immediately following piglets weaning, by weaning weight.

\begin{tabular}{|c|c|c|c|c|c|c|c|c|}
\hline Piglet weaning weight & Physical form & $\begin{array}{c}\mathrm{LW}^{1} 21 \\
\text { days (kg) }\end{array}$ & $\mathrm{DFI}^{2}(\mathrm{~g})$ & $\mathrm{DWG}^{3}(\mathrm{~g})$ & $\mathrm{FC}^{4}\left(\mathrm{~g} \mathrm{~g}^{-1}\right)$ & $\mathrm{FW}^{5}(\%)$ & $\begin{array}{l}\mathrm{DFI}^{2}-\mathrm{FW}^{5} \\
\quad(\mathrm{~g})\end{array}$ & $\begin{array}{c}\mathrm{LW}^{2} 28 \\
\text { days }(\mathrm{kg})\end{array}$ \\
\hline Heavy & Pellet & 6.34 & 242 & 248 & 0.99 & 2.05 & 237 & 8.07 \\
\hline Heavy & Meal & 6.32 & 215 & 160 & 1.42 & 9.52 & 195 & 7.44 \\
\hline Light & Pellet & 5.83 & 223 & 244 & 0.92 & 1.32 & 220 & 7.54 \\
\hline Light & Meal & 5.82 & 186 & 127 & 1.50 & 8.78 & 170 & 6.71 \\
\hline \multicolumn{9}{|c|}{ 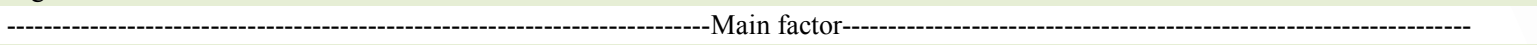 } \\
\hline \multicolumn{2}{|c|}{ Light-weight piglet at weaning } & 5.82 & 205 & 185 & 1.21 & 5.05 & 195 & 7.12 \\
\hline \multicolumn{2}{|c|}{ Heavy-weight piglet at weaning } & 6.32 & 228 & 203 & 1.20 & 5.78 & 216 & 7.75 \\
\hline \multicolumn{2}{|l|}{ Meal } & 6.07 & 200 & 143 & 1.46 & 9.15 & 182 & 7.07 \\
\hline \multicolumn{2}{|l|}{ Pellet } & 6.08 & 232 & 246 & 0.95 & 1.68 & 228 & 7.80 \\
\hline \multicolumn{9}{|c|}{ 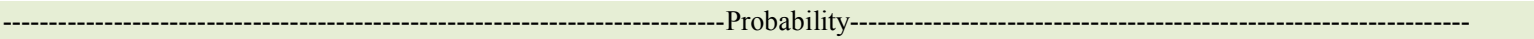 } \\
\hline \multicolumn{2}{|l|}{ Weaning weight } & 0.001 & 0.230 & 0.412 & 0.991 & 0.081 & 0.269 & 0.001 \\
\hline \multicolumn{2}{|l|}{ Physical form } & 0.697 & 0.107 & 0.001 & 0.001 & 0.001 & 0.019 & 0.001 \\
\hline \multicolumn{2}{|l|}{ Interaction } & 0.958 & 0.791 & 0.509 & 0.275 & 0.994 & 0.823 & 0.563 \\
\hline \multicolumn{2}{|l|}{$\mathrm{CV}^{5}$} & 1,77 & 22,72 & 28,43 & 15,21 & 19,13 & 23,11 & 5,88 \\
\hline
\end{tabular}

$\mathrm{LW}^{1}$ - live weight at a given age; $\mathrm{DFI}^{2}$ - mean daily feed intake; $\mathrm{DWG}^{3}$ - mean daily weight gain; $\mathrm{FC}^{4}$ - feed conversion; $\mathrm{FW}^{5}$ - feed waste during the period; $\mathrm{CV}^{5}$ - coefficient of variation.

In contrast, the use of a pelleted diet during the nursery phase has been reported by two authors to improve the FC with no effect on DWG and DFI. LUNDBLAD et al. (2011) tested various heat processing treatments (pelleting at $47^{\circ} \mathrm{C}$, pelleting at $90^{\circ} \mathrm{C}$, expansion at $105^{\circ} \mathrm{C}$, and extrusion at $120^{\circ} \mathrm{C}$, $4.0 \mathrm{~mm}$ pellet size) for a wheat meal, soybean meal, and fish flour-based diet for weaning pigs and observed a better FC, with no effect on DFI or DWG compared to the corresponding meal diet. The authors attributed this improvement to a decreased FW. MEDEL et al. (2004) observed a 20\% improvement in FC with the use of a pelleted diet $(2.5 \mathrm{~mm})$ conditioned at 70 $75^{\circ} \mathrm{C}$. However, this improvement was accompanied by a $15.5 \%$ decrease in DFI, with no difference in DWG. The authors attributed the improvement in FC partially to the $3.6 \%$ higher digestibility coefficient of gross energy of the pelleted diet and to the decrease in FW (measured in a subsequent experiment conducted under the same conditions to be $8.9 \%$ for the meal diet and $2.3 \%$ for the pelleted diet).

STEIDINGER et al. (2000) observed that the pelleting of corn, soybean meal, dairy products, and plasma-based diets at temperatures greater than $77^{\circ} \mathrm{C}$ had negative effects on DWG and DFI from 0 to 7 days following weaning. However, there were no significant differences between piglets fed pelleted $(3.9 \mathrm{~mm})$ and meal diets from 0 to 28 days following weaning.

A 28\% improvement in FC during the first week and a $22 \%$ improvement for the weaning period until 40 days of age were observed $(\mathrm{P}<0.05$, Table 3$)$, which can be attributed to the decrease in FW and the increase in digestible energy of the pelleted diet. An evaluation of the digestibility of the diet for piglets from 37 to 40 days of age revealed a higher digestible energy for the pelleted diet $\left(3,626 \mathrm{kcal} \mathrm{kg}^{-1}\right)$ than for the meal diet $\left(3,424 \mathrm{kcal} \mathrm{kg}^{-1}\right)$ (P 0.023). Pelleting consisted of the application of hot vapor and mechanical pressure to form pellets, and these processes can improve the diet digestibility (MEDEL et al., 2004).

Diet digestibility can also partially determine the DFI of young piglets because digestibility is positively related to feed intake (DONG \& PLUSKE, 2007). Therefore, the increase in diet digestibility resulting from processing may have had a positive effect on DFI during the period immediately following weaning. Avoiding decreases in feed intake is desirable by piglets during post-weaning because the intake level is more strongly related than the diet composition to the preservation of the integrity of intestinal villi (BEERS-SCHREURS et al., 1998).

A significant interaction between piglet weight and the physical form of the diet was observed for the DWG from 29 to 40 days of age (P 0.042). Heavy-weight piglets receiving a pelleted diet had a greater DWG than light-weight piglets. In contrast, for the meal diet, there was no significant difference in DWG between piglets with different initial weaning weights.

This interaction indicated a favorable effect of the pelleted diet on the DWG of the heavy- 
Table 3 - Effect of the physical form of the pre-starter diet on the zootechnical performance and the energy digestibility of piglets, by weaning weights.

\begin{tabular}{lcccccccc}
\hline & & & & & & & & \\
\hline
\end{tabular}

Means followed by the same lower case letter within the same row differ according to the Tukey test $(\mathrm{P}<0.05)$; $\mathrm{DFI}^{1}$ - mean daily feed intake; $\mathrm{DWG}^{2}$ - mean daily weight gain; $\mathrm{FC}^{3}$ - feed conversion; $\mathrm{LW}^{4}$ - live weight at a given age; $\mathrm{DE}^{5}$ - digestible energy (37 to 40 days of age); $\mathrm{CV}^{5}$ - coefficient of variation.

weight animals. The DWG is determined by the genetic potential of an animal and its ability to ingest the amount of required nutrients.

No differences in performance were observed between light-weight and heavy-weight piglets during the first week following weaning $(\mathrm{P}>0.05)$. Effect of the weight difference on performance during this first week may have been attenuated by weaning stress. However, the initial weight of a piglet at weaning affected performance at 40 days of age, with higher final DFI, DWG and LW values for heavy-weight piglets, but no significant differences in FC $(\mathrm{P}<0.05)$. WOLTER et al. (2002) evaluated the effect of weight at birth and liquid supplementation at the farrowing pen. The authors compared heavy-weight $(6.6 \mathrm{~kg})$ and light-weight $(5.7 \mathrm{~kg})$ piglets at weaning and observed higher DWG and DFI values and improvement in $\mathrm{FC}$ at weaning for heavy-weight piglets from weaning up to $14 \mathrm{~kg}$.

The difference in DFI between light-weight and heavy-weight piglets may be related to the capacity of the gastrointestinal tract (GIT) because bigger piglets were observed to have larger GITs (PLUSKE et al., 2003). Interestingly, the relative weight ( $\%$ LW) of the GIT was previously observed to be higher in lighter piglets weaned at 14 days, and this difference decreased as the post-weaning time passed (PLUSKE et al., 2003). This pattern may explain why no differences in DFI were observed between light-weight and heavy-weight piglets during the first post-weaning week.

Regarding the residual effects of the evaluated diets determined when all of the animals received a pelleted diet (Table 4), a greater FC was observed for animals that had previously received meal than for animals that had previously received a pelleted diet and for the light-weight animals relative to the heavy-weight animals at weaning $(\mathrm{P}<0.05)$. A possible explanation for this could be the decrease in maintenance energy associated with the lower LW of these groups. MAHAN et al. (1998) observed a worse FC during the nursery phase for heavier piglets and attributed this observation to the lower demand for maintenance energy of light-weight piglets.

A significant effect of the initial weaning weight on the LW in the subsequent periods was only observed until 56 days of age (P 0.01), and a $0.5 \mathrm{~kg}$ difference at weaning represented a $1.6 \mathrm{~kg}$ difference at 56 days of age. No effect was observed after 56 days of age (at 100 and 130 days of age) (Table 2, 3 and 4). At 40 days of age, animals that had received a pelleted diet were $2.05 \mathrm{~kg}$ heavier than those that received a meal diet (P 0.001). The additional weight difference resulting from the use of a pre-starter diet remained significant between 40 and 100 days of age (P 0.046), representing a $0.40 \mathrm{~kg}$ increase relative to the weight difference observed at 40 days of age. 
Table 4 - Residual effect of the physical form of the pre-starter diet and weaning weight on the zootechnical performances and live weights of piglets at subsequent growth phases.

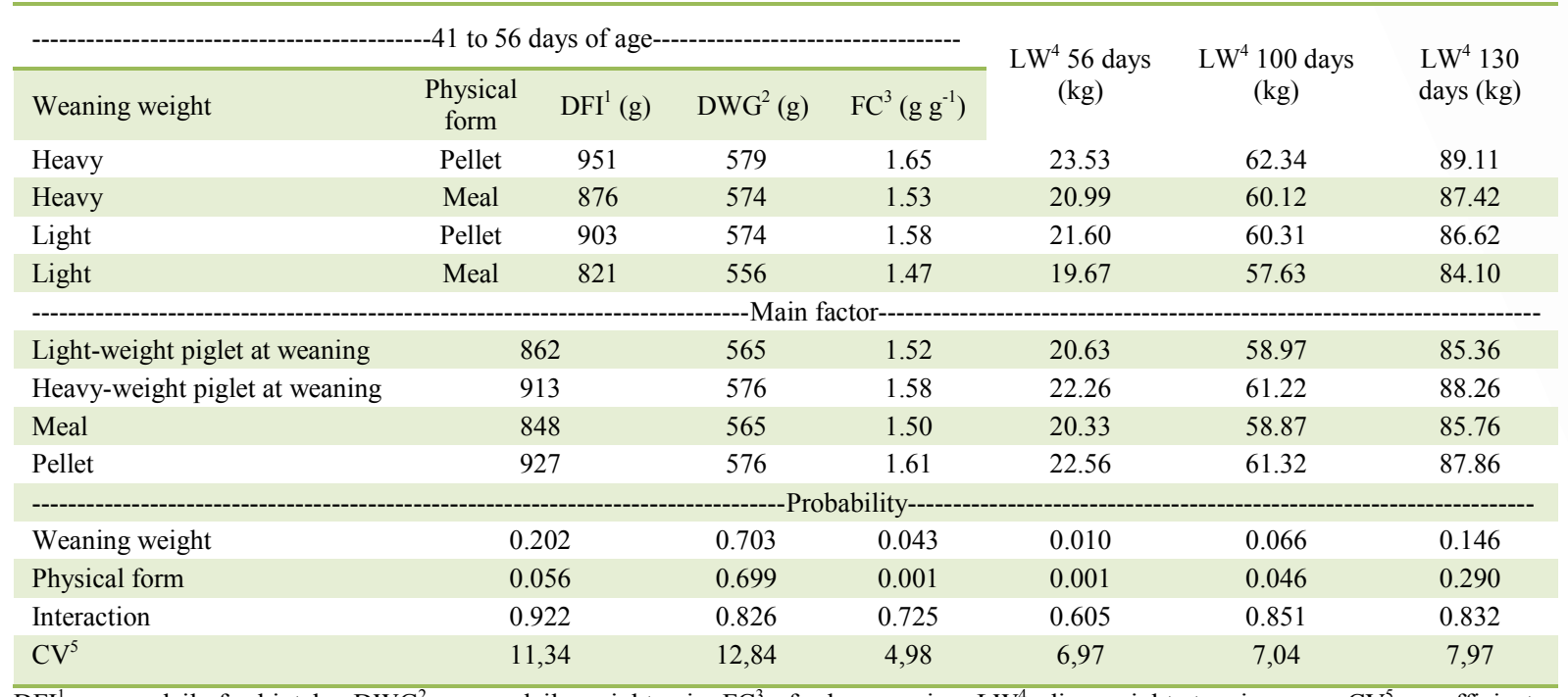

$\mathrm{DFI}^{1}$ - mean daily feed intake; $\mathrm{DWG}^{2}$ - mean daily weight gain; $\mathrm{FC}^{3}$ - feed conversion; $\mathrm{LW}^{4}$ - live weight at a given age; $\mathrm{CV}^{5}$ - coefficient of variation.

WOLTER et al. (2002) observed a $0.9 \mathrm{~kg}$ weight difference at weaning in piglets with different weights at birth $(1.3$ vs. $1.8 \mathrm{~kg})$ and between piglets that did or did not receive supplementation at the farrowing pen. However, the weight at birth had a stronger effect on the subsequent performance and the time required to reach slaughter weight than supplementation at the farrowing pen.

\section{CONCLUSION}

Pelleting improved the performance of weaning pigs and the digestibility of the pre-starter diet. However, there wasn't residual effect of the physical form on weight at slaughter. Piglet weight at weaning should be considered an important factor because had impact on weight gain at the initial nursery phase, but without expressive effect on other phases.

\section{BIOETHICS AND BIOSSECURITY COMMITTEE APPROVAL}

Protocol n. 059/2011.

\section{REFERENCES}

BEERS-SCHREURS, H. M. G. et al. Weaning and the weanling diet influence the villus height and crypt depth in the small intestine of pigs and alter the concentrations of short-chain fatty acids in the large intestine and blood. Journal Nutrition, v.128, n.6, p.947-953, 1998. Available from: <http://jn.nutrition.org/ content/128/6/947.long > . Accessed: Jan. 06, 2012.

BURRIN, D. G; STOLL, B. Intestinal nutrient requirements in weanling pigs. In: PLUSKE, J. R. et al. The weaner pig: concepts and consequences. Wageningen: Academic Publishers, 2003. p.301-335.

DONG, G. Z.; PLUSKE, J. R. The low feed intake in newly-weaned pigs: problems and possible solutions. Asian-Australasian Journal of Animal Sciences, v.20, n.3, p440-453, 2007. Available from: <http://www.ajas. info/Editor/manuscript/upload/20-60.pdf $>$. Accessed: Nov. 20, 2011.

HANCOCK, J. D.; BEHNKE, K. C. Use of ingredient and diet processing technologies to produce quality feeds for pigs. In: LEWIS, A. J.; SOUTHER, L. L. (Eds.). Swine nutrition. 2. ed. Boca Raton, FL: CRS, 2001. p.469-492.

KAVANAGH, S. et al. A comparison of total collection and marker technique for the measurement of apparent digestibility of diets for growing pigs. Animal Feed Science and Technology, v.89, p.49-58, 2001. Available from: $<$ http://www.sciencedirect.com/science/article/pii/S0377840100002376\#>. Accessed: Nov. 20, 2011. doi: S0377-8401(00)00237-6.

LUNDBLAD, K. K. et al. Effects of steam conditioning at low and high temperature, expander conditioning and extruder processing prior to pelleting on growth performance and nutrient digestibility in nursery pigs and broiler chickens. Animal Feed Science and Technology, v.169, p.208-217, 2011. Available from: <http://www.animalfeedscience.com/ article/S0377-8401(11)00285-9/abstract>. Accessed: Nov. 10, 2013. doi: S0377-8401(00)00237-6. 10.1016/j.anifeedsci.2011.06.008.

MAHAN, D. C. et al. Evaluation of the feeding duration of a phase 1 nursery diet to three-week-old pigs of two weaning weights. Journal of Animal Science, v.76, p.578-583, 1998. Available from: <http:// jas.fass.org/content/76/2/578>. Accessed: 05 jan. 2012. 
MAHAN, D. C.; LEPINE, A. J. Effect of pig weaning weight and associated feeding programs on subsequent performance to 105 kilograms body weight. Journal of Animal Science, v.69, p.1370-1378, 1991. Available from: <http:/www.ncbi.nlm.nih.gov/ pubmed/2071501>. Accessed: Apr. 11, 2011.

MEDEL, P. et al. Heat processing of cereals in mash or pellet diets for young pigs. Animal Feed Science and Technology, v.113, p.127-140, 2004. Available from: <http://www.sciencedirect.com/ science/article/pii/S0377840103002517>. Accessed: Apr. 11, 2011. doi: 10.1016/j.anifeedsci.2003.08.005

MOREIRA, I. et al. Utilização da farinha pré-gelatinizada de milho na alimentação de leitões na fase de creche, digestibilidade e desempenho. Revista Brasileira de Zootecnia, v.30, n.2, p.440-448, 2001. Available from: <http://www.scielo.br/pdf/rbz/v30n2/5486. pdf $>$. Accessed: Feb. 11, 2012.

MOUGHAN, P. J. et al. Chromic oxide and acid-insoluble ash as faecal markers in digestibility studies with young growing pigs. New Zealand Journal of Agricultural Research, v.34, p.85-88, 1991. Available from: <http://dx.doi.org/10.1080/00288233.1991.1041779 6>. Accessed: Apr. 11, 2011.

$\mathrm{OHH}, \mathrm{S} . \mathrm{H}$. et al. Effects of feed processing methods on growth performance and ileal digestibility of amino acids in young pigs. Asian-Australian Journal Animal Science, v.15, n.12, p.1765-1772, 2002. Available from: <http://www.ajas.info/editor/ manuscript/upload/15_280.pdf $>$. Accessed: Jan. 09, 2012.
PLUSKE, J. R. et at. Age, sex and weight at weaning influence the physiological and gastrointestinal development of weanling pigs. Australian Journal of Agricultural Research, v.54, p.515-527, 2003.

ROSTAGNO, H. S. et al. Composição de alimentos e exigências nutricionais. (Tabelas brasileiras para aves e suínos). Viçosa, MG: UFV, 2005. 186p.

STEIDINGER, M. U. et al. Effects of pelleting and pellet conditioning temperatures on weanling pig performance. Journal of Animal Science, v.78, p.3014-3018, 2000. Available from: <http://www.ncbi. nlm.nih.gov/pubmed/11132814>. Accessed: Apr. 11, 2011.

VAN KEULEN, J.; YOUNG, B. A. Evaluation of acidinsoluble ash as a natural marker in ruminant digestibility studies. Journal of Animal Science, v.44, p.282-287, 1977.

WOLTER, B. F. et al. The effect of birth weight and feeding of supplemental milk replacer to piglets during lactation on preweaning and postweaning growth performance and carcass characteristics. Journal of Animal Science, v.80, p.301308, 2002. Available from: <http://www.ncbi.nlm.nih.gov/ pubmed/11881919>. Accessed: Apr. 11, 2011.

XING, J. J. et al. Effects of emulsification, fat encapsulation, and pelleting on weanling pig performance and nutrient digestibility. Journal of Animal Science, v.82, p.2601-2609, 2004. Available from: <http://www.journalofanimalscience.org/content/82/9/2601. long>. Accessed: Nov. 11, 2013. 